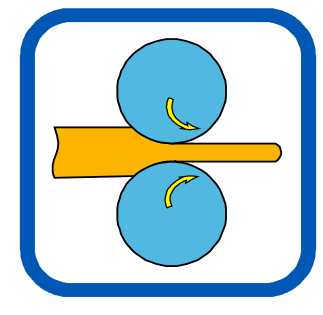

УДК 621.778 .1

\section{РАЗДЕЛ III \\ ПРОЦЕССЫ ОБРАБОТКИ ДАВЛЕНИЕМ В МЕТАЛЛУРГИИ}

DOI: $10.37142 / 2076-2151 / 2020-1(50) 217$

Аніщенко О. C. Кухар B. B. Присяжний А. Г.

\title{
РОЗРОБКА РЕЖИМІВ ХОЛОДНОГО ВОЛОЧІННЯ ДРОТУ, ЩО БУВ ПЕРЕГРІТИЙ ПРИ ТЕРМООБРОБЦІ
}

Аналіз сучасного стану та перспектив волочіння дроту показує $[1,2]$, що в світі існують тенденції до розширення номенклатури матеріалів за хімічним складом, вихідним станом, фінішними механічними властивостями і пов'язаним з цим зменшенням серійності виробництва. Удосконалення технологій волочіння дрібними партіями дозволяє виготовляти напівфабрикати для штамповки та дріт з експлуатаційними властивостями і за режимами [3-6], що є недоступними для станів багаторазового волочіння. Все ширше використовується рециклінг зношеного або дефектного дроту [7].

Зокрема, дефекти можуть з'являтися при волочінні стального дроту з проміжними відпалами, коли можливий перегрів окремих мотків дроту. 3-за погіршення механічних властивостей подальша його обробка тиском практично неможлива. Усувають дефекти перегріву зазвичай додатковою термообробкою $[8,9]$, що збільшує вартість дроту.

Мета цієї роботи - розробка режимів холодного волочіння перегрітого дроту, які забезпечують суцільність металу в процесі деформації з одночасним збільшенням його міцності.

Досліджували дріт зі сталі Ст. 2 з вихідним діаметром 4 мм, змотаний в мотки масою 1 т кожний, які при $1140-1160{ }^{\circ} \mathrm{C}$ і витримці при цій температури протягом трьох годин зазнали перегріву. Режими холодного волочіння відпрацьовували при швидкостях волочіння 2,25 - 0,086 м / с. Відпал зразків проводили в електропечі при $900-930{ }^{\circ} \mathrm{C}$ з витримкою дві години. Механічні властивості дроту досліджували за ГОСТ 10446-80 на машині Р-0,5.

Металографічні дослідження показали, що в поздовжньому і поперечному перетинах дроту зерна, що утворилися після перегріву при $1140-1160{ }^{\circ} \mathrm{C}$, дрібні і рівновісні. Діаметр їх коливається в межах від 6 до 24 мкм в поперечному і від 5 до 70 мкм в поздовжньому перетині дроту. За шкалою ГОСТ 5639-82 розмір зерна відповідає 8-10-му номеру, що свідчить про перегрів досліджуваного металу.

Термомеханічну обробку (ТМО) дроту проводили за режимами:

1. Холодне волочіння (властивості відповідають ГОСТ 3282-74).

2. Холодне волочіння + відпал (властивості відповідають ГОСТ 3282-74).

3. Холодне волочіння + перегрів.

4. Холодне волочіння + перегрів + холодне волочіння.

5. Холодне волочіння + перегрів + холодне волочіння + відпал.

Властивості дроту після ТМО наведені в табл. 1.

Перегрів дроту різко знижує його пластичність: відносне подовження зразків знижується в 4,5-10 разів у порівнянні з граничним значенням, регламентованим ГОСТ 3282-74. Через товстий шар окалини на поверхні, невисокі значення тимчасового опору і границі текучості при аномально низькій пластичності використання дроту неможливо навіть в якості обв'язувального матеріалу. Виявилися неприйнятними стандартні технологічні процеси, рекомендовані авторами [1] для волочіння вуглецевих сталей: дріт неможливо було очистити 
від окалини, оскільки багаторазовий вигин між роликами машини приводив до його обриву. Травлення великогабаритних мотків в сірчаній кислоті не забезпечувало видалення окалини на витках дроту, розташованих в центральній частині мотків.

Найбільш прийнятним варіантом очищення поверхні дроту виявилося протягування його перед входом у волокоутримувач через п'ять зношених волок з початковим діаметром робочого каналу, рівним діаметру дроту. У цьому випадку основний шар окалини збивався зношеними волоками, а іiї залишки у вигляді дрібних крупинок обсипалися на першому волочильному проході в мильницю при вході дроту в деформуючу волоку.

Холодне волочіння перегрітого дроту за стандартними режимами [1] супроводжувалося частими обривами, особливо на першому проході. Частота обривів не залежала від використовуваного мастила. 3 огляду на це, волочіння на першому проході в подальшому проводили без змащення, а, починаючи з другого проходу, під час волочіння практично чистого від окалини дроту застосовували сухий порошок господарського мила.

Таблиця 1

Механічні властивості дроту після різних режимів ТМО

\begin{tabular}{|c|c|c|c|c|c|}
\hline $\begin{array}{c}\text { Діаметр } \\
\text { дроту, мм }\end{array}$ & $\begin{array}{c}\text { Номер режиму } \\
\text { термомеханічної } \\
\text { обробки }\end{array}$ & $\begin{array}{c}\text { Тимчасовий } \\
\text { опір } \sigma_{B}, \\
\text { МПа }\end{array}$ & $\begin{array}{c}\text { Границя } \\
\text { текучості } \\
\sigma_{T}, \text { МПа } \\
\end{array}$ & $\begin{array}{c}\text { Відносне } \\
\text { подовження } \\
\delta, \% \\
\end{array}$ & $\begin{array}{c}\text { Відносне } \\
\text { звуження } \\
\psi, \% \\
\end{array}$ \\
\hline \multirow{3}{*}{4,0} & 1 & $440-530$ & - & - & - \\
\hline & 2 & $290-490$ & - & 20 & - \\
\hline & 3 & $361-372$ & $206-221$ & $2,0-4,6$ & $68-71$ \\
\hline \multirow{4}{*}{3,0} & 1 & $540-1080$ & - & - & - \\
\hline & 2 & $290-490$ & - & 20 & - \\
\hline & 4 & $581-598$ & $574-597$ & $3,3-4,0$ & $56-60$ \\
\hline & 5 & $283-290$ & - & $38-45$ & $62-65$ \\
\hline \multirow{4}{*}{2,55} & 1 & $540-1080$ & - & - & - \\
\hline & 2 & $290-490$ & - & 20 & - \\
\hline & 4 & $610-645$ & $595-618$ & $1,6-1,8$ & $51-56$ \\
\hline & 5 & $270-272$ & - & $37-40$ & $54-58$ \\
\hline \multirow{4}{*}{2,05} & 1 & $590-1180$ & - & - & - \\
\hline & 2 & $290-490$ & - & 15 & - \\
\hline & 4 & $723-765$ & $570-741$ & $2,0-3,3$ & $47-54$ \\
\hline & 5 & $269-277$ & - & $25,5-31,5$ & $50-56$ \\
\hline
\end{tabular}

Обриви дроту при волочінні відбувалися між деформуючою волокою і фігуркою 3 насадженим на неї мотком дроту, в губках затискних кліщів і між кліщами та деформуючою волокою. Причинами обривів дроту на їі вході в деформуючу волоку з'явилися підвищена швидкість волочіння, велика маса мотка і низька границя текучості матеріалу дроту. У початковий момент деформації дроту при швидкості волочіння 0,418 м/ с зусилля протинатягнення $Q$, необхідне для розкручування мотка на опорному підшипнику фігурки, перевищувало 2,5 кН. Напруження протинатягнення, що виникало при цьому, $\sigma_{Q}=Q / F_{0}\left(F_{0}-\right.$ площа пе- 
ретину дроту на вході в деформуючу волоку) перевищувало границю текучості перегрітої сталі (див. табл. 1). Це викликало пластичну деформацію дроту до його волочіння і наступний обрив через низьку пластичність $(\delta=2,0-4,6 \%$ ). Суцільність металу була збережена шляхом зниження швидкості волочіння до 0,245 м / с і поділу мотка дроту після першого волочильного проходу на бухти з масою 60-80 кг, які не викликали істотного сплеску зусилля протинатягнення на наступних проходах навіть при дворазовому збільшенні швидкості волочіння.

Обриви дроту в кліщах на виході з деформуючої волоки були усунені експериментальним підбором оптимальних швидкості волочіння $V$ i витяжки на $i$-му проході $\mu_{i}\left(\mu_{i}=d_{i-1}^{2} / d_{i}^{2}\right.$, де $d_{i-1}$ i $d_{i}$ - діаметри дроту до і після волочіння на $i$-му проході), що враховують допустимий знос волок: 1-й прохід $-V=0,245$ м / c, $\mu_{1}=1,27-1,34$; 2-й прохід $V=0,418$ м / с, $\mu_{2}=1,29-1,52$; наступні проходи $-V=0,518$ м / с, $\mu_{i}=1,20-1,38$.

Механічні властивості дроту діаметром 2,55 і 2,05 мм (див. табл. 1), отриманого холодним волочінням за обраними режимами, виявилися прийнятними для його подальшої переробки в цвяхи або використання в якості обв'язувального матеріалу. Підвищення міцності при холодному волочінні дроту з дефектами перегріву виявилося значно інтенсивнішим, ніж при холодній прокатці тієї ж сталі [10-12]. Залежність тимчасового опору і границі текучості дроту від витяжки була апроксимована наступними формулами:

$$
\sigma_{B}=366,9+560,0\left(1-\frac{1}{\sqrt{\mu}}\right)^{0,74} ; \sigma_{T}=209,0+714,1\left(1-\frac{1}{\sqrt{\mu}}\right)^{0,63}
$$

Дані табл. 1 показують, що відпал зразків дроту в початковому стані і після волочіння нахолодно не забезпечує необхідні для ГОСТ 3282-74 значення тимчасового опору, проте на порядок і більше збільшує відносне подовження наклепаного дроту, що дозволяє використовувати його для виготовлення заклепок і гнуття гачків.

3 метою прогнозування технологічних режимів волочіння некондиційного дроту інших діаметрів та зі сталі інших марок на основі результатів проведеного експерименту було досліджено напружено-деформований стан дроту в початковий момент волочіння.

Після вальцювання в наточувальному верстаті кінцева ділянка дроту має діаметр на $\Delta_{i}$ менше, ніж діаметр деформуючої волоки. Внаслідок низької межі плинності сталі Ст.2 і частково через зношування рівчаків наточувального верстата на поверхні дроту утворюються поздовжні задирки, які в початковий момент волочіння або мнуться, або зрізаються волокою. У будь-якому випадку в зоні контакту дроту з волокою деформаційне тертя максимально, тобто коефіцієнт тертя $f=0,5$.

При найбільш несприятливому для волочіння варіанті зрізання задирок волокою в розрахунках силового режиму волочіння слід взяти до уваги зусилля зрізу, що визначається за формулою [13]:

$$
P_{i}=1,4\left(\sigma_{B}\right)_{i} S,
$$

де $\left(\sigma_{B}\right)_{i}$ - тимчасовий опір матеріалу дроту на виході з деформуючої волоки з робочим діаметром $d_{i}$;

$S$ - площа зрізу задирки.

Оскільки при заточуванні кінців дроту 3 перегрітої сталі в зоні переходу $\left(d_{i}-\Delta_{i}\right) \rightarrow d_{i-1}$ утворюються дві діаметрально протилежних поздовжніх задирки товщиною $h$ і шириною $\left(1,15 d_{i-1}-d_{i}\right)$, під час волочіння з витяжкою $\mu_{i}$ питоме зусилля зрізу задирок з урахуванням виміряних значень $h$ і $1,15 d_{i-1}$ може досягати: 


$$
P_{i}=K_{c} \mu_{i}\left(\sigma_{B}\right)_{i}
$$

де $K_{c} \sim 0,1$.

Експерименти показали, що коефіцієнт $K_{c}$ залежить від матеріалу дроту і становить для наклепаної латуні $\sim 0,14$, для корозійностійкої сталі $\sim 0,18$, для титану $\sim 0,2$.

Зусилля, що розвивається волочильним станом в початковий момент деформації, викликає на ділянці між кліщами і деформуючою волокою змінне по довжині дроту напруження, мінімум якого фіксується на виході з волоки і визначається діаметром $d_{i}$. На ділянці між деформуючою волокою і кліщами це напруження в $d_{i}^{2} /\left(d_{i}-\Delta_{i}\right)^{2}$ разів більше мінімального. При затиску дроту в кліщах губки проникають в тіло дроту з протилежних сторін на глибину $\eta$, перетин дроту в цьому місці зменшується на:

$$
S_{R}=R^{2} \arccos \frac{R-\eta}{R}-\sqrt{2 R \eta-\eta^{2}}(R-\eta)
$$

де $R$ - радіус загостреного кінця дроту, $R=\frac{d_{i}-\Delta_{i}}{2}$.

3 урахуванням виміряних значень $\eta$ під час волочіння на і-тому проході напруження в місці затиску дроту кліщами $\left(\sigma_{B}\right)_{i}$ буде в $d_{i}^{2} / 0,8\left(d_{i}-\Delta_{i}\right)^{2}$ разів більше, ніж на виході $з$ деформуючої волоки.

Для того, щоб дріт не порвався в початковий момент волочіння на i-тому проході, необхідне виконання умови:

$$
\left(\sigma_{B}^{\prime}\right)_{i}^{>}\left(\sigma_{B}\right)_{i}
$$

де $\left(\sigma_{B}^{\prime}\right)_{i}$ - тимчасовий опір в місці затиску дроту кліщами після загострення

вальцюванням на діаметр $d_{i}-\Delta_{i}$ з витяжкою $\mu_{0}=D /\left(d_{i}-\Delta_{i}\right)$.

Скористаємося формулою Кербера і Ейхінгера [8] для визначення напруження волочіння і з урахуванням (3) запишемо нерівність (5) в наступному вигляді:

$$
\frac{0,8\left(d_{i}-\Delta_{i}\right)^{2}}{d_{i}^{2}}\left(\sigma_{B}^{\prime}\right)_{i}^{>} \frac{\left(\sigma_{B}\right)_{i}+\left(\sigma_{B}\right)_{i-1}}{2}\left\{\frac{b}{a}\left[1-\left(\frac{1}{\sqrt{\mu_{i}}}\right)^{a}\right]+0,77 \operatorname{tg} \alpha\right\}+\sigma_{Q}\left(\frac{1}{\sqrt{\mu_{i}}}\right)^{a}+0,1 \mu_{i}\left(\sigma_{B}\right)_{i},
$$

де $\left(\sigma_{B}\right)_{i-1}-$ тимчасовий опір дроту на $i$-тому волочильному проході перед входом в деформуючу волоку;

$a=f c t g \alpha ; b=1+f c t g \alpha ; \alpha-$ напівкут волоки, $\alpha=7,5^{\circ}$.

Аналіз нерівності (6) показує, що силовий режим початкової стадії волочіння, який визначається правою частиною нерівності (6), викликає в перерізі дроту напруження, обумовлені на 13-15 \% зусиллям зрізу задирок і на 30-35 \% протинатягненням, внесок якого тим вище, чим більше витяжка за прохід. Коефіцієнт тертя в даному випадку змінити практично неможливо, а доданок $0,77 \operatorname{tg} \alpha$ при всіх рекомендованих для сталей значеннях $\alpha$ може бути замінено на 0,1 . При збільшенні $\Delta_{i}$ хоча і підвищується тимчасовий опір металу на ділянці загострення, проте значення лівої частини нерівності (6) зменшується.

Таким чином, основними факторами, що впливають на граничну витяжку перегрітого дроту з характеристиками міцності, обумовленими формулами (1), є напруження протинатягнення, питоме зусилля зрізу задирок і різниця між діаметром деформуючої волоки і діаметром загостреного кінця дроту. 
На рис. 1 показані результати розрахунків сталого режиму волочіння на першому проході з використанням нерівності (6). Графіки показують, що при зниженні швидкості волочіння з 0,418 до 0,245 м / с зменшується напруження протинатягнення з 203 до 163,8 МПа, гранична витяжка збільшується за прохід з 1,025; 1,05 і 1,108 до 1,09; 1,11 і 1,17 відповідно для діаметра дроту 0,6; 0,6 і 0,1 мм, тобто діаметр дроту на виході з волоки можна зменшити на 0,1 мм. Такий же результат можна отримати при зменшенні різниці між діаметром загостреного кінця дроту і діаметром волоки з 0,5 до 0,1 мм. У зв'язку з цим для запобігання обривів дроту доцільно вибирати маршрути волочіння з урахуванням наявних розмірів калібрів валків в наточувальному верстаті. Діаметр дроту на кожному проході повинен бути підібраний так, щоб він для розглянутого випадку не більше ніж на $15 \%$ перевищував діаметр його кінцевої ділянки після загострення у відповідному калібрі.

У разі, якщо вдалося б усунути зминання і зрізання задирок на дроті $\left(P_{i}=0\right)$, гранична витяжка на першому проході зросла 6 з 1,05 до 1,135 ( $\sigma_{Q}=203 \mathrm{MПа),} \mathrm{так} \mathrm{як} \mathrm{маршрут} \mathrm{воло-}$ чіння $4 \rightarrow 3,9$ мм можна було б замінити на $4 \rightarrow 3,75$ мм.

Практична перевірка критерію сталості (5) показала його прийнятність для розробки технології волочіння перегрітого дроту. Зокрема, як видно на рис. 1, витяжку за один прохід можна істотно збільшити, знизивши протинатягнення за рахунок примусового розкручування мотка на фігурці з лінійною швидкістю на 20-30 \% меншою, ніж швидкість волочіння $(0,245$ м / c). У цьому випадку зникає сплеск зусилля протинатягнення, що дозволяє використовувати на першому проході деформуючу волоку діаметром 3,45 мм при $\Delta_{1}=0,25$ мм.

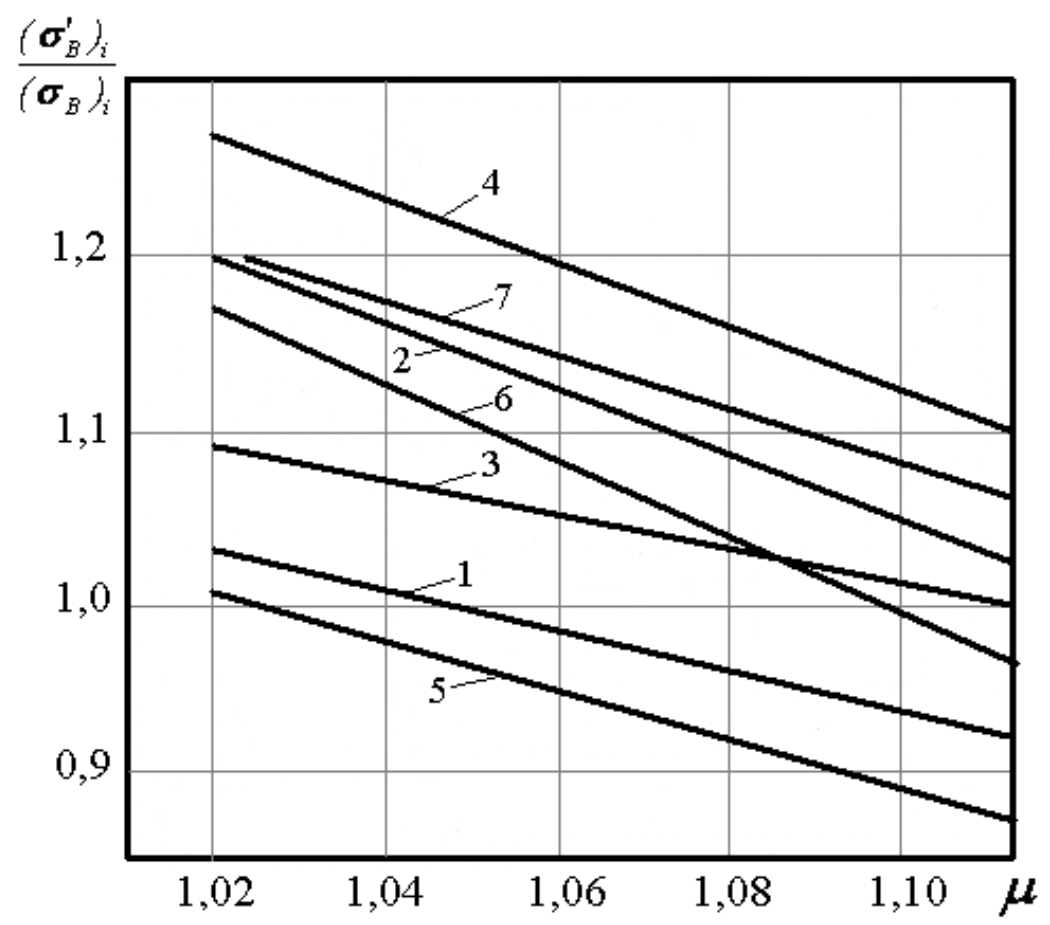

Рис. 1. Вплив витяжки $\mu$ на сталість волочіння дроту на першому проході:

$1-\Delta_{i}=0,5 \mathrm{мм}, \sigma_{Q}=203,0 \mathrm{MПа} ; 2-\Delta_{i}=0,5 \mathrm{mM}, \sigma_{Q}=163,8 \mathrm{MПа} ;$

$3-\Delta_{i}=0,1 \mathrm{мм}, \sigma_{Q}=203,0 \mathrm{MПа} ; 4-\Delta_{i}=0,1 \mathrm{мM}, \sigma_{Q}=163,8 \mathrm{MПа}$;

$5-\mu_{0}=1,38, \sigma_{Q}=203,0 \mathrm{M \Pi а} ; 6-\mu_{0}=1,38, \sigma_{Q}=163,8 \mathrm{M \Pi а}$

$7-\Delta_{i}=0,5 \mathrm{MM}, \sigma_{Q}=203,0 \mathrm{M \Pi а}, R_{i}=0$

Волочіння дроту на другому проході протікає в умовах, що змінилися. Під час вальцювання в наточувальному верстаті діаметр кінця дроту зменшується до 2,52 мм. Змащування 
мильним порошком сприяє на усталеній стадії волочіння зниженню коефіцієнта тертя з 0,5 до 0,1. При більш легкій фігурці з укладеною на неї бухтою масою не більше 80 кг, при швидкості волочіння 0,418 м / с напруження протинатягнення знижується до 46 МПа. У цих умовах розрахунок за критерієм сталості (5) передбачає граничну витяжку на другому проході $\mu_{2}=1,52$ за маршрутом волочіння $3,45 \rightarrow 2,80$ мм, для якого $\left(\sigma_{B}^{\prime}\right)_{2} /\left(\sigma_{B}\right)_{2}=1,03$.

На третьому проході необхідно виготовити дріт діаметром 2,55 мм, що здійснюється зі швидкістю волочіння 0,518 м / с. За умовами волочіння допускається зменшення діаметра деформуючої волоки до 2,32 мм.

На четвертому проході мм виявилося неможливим волочіння дроту по маршруту $2,55 \rightarrow 2,05$ мм, оскільки через загострення кінця дроту на діаметр 1,67 мм він обривався в кліщах в початковий момент волочіння. Перевірка цього експериментального факту аналітичними розрахунками за нерівністю (6) підтвердила ймовірність обриву дроту: $\left(\sigma_{B}^{\prime}\right)_{i} /\left(\sigma_{B}\right)_{i}=0,88$. У зв'язку з цим маршрути волочіння на четвертому і п'ятому проходах $2,55 \rightarrow 2,32 \rightarrow 2,05$ мм були обрані виходячи з наявності деформуючої волоки діаметром 2,32 мм. Слід зазначити, що п'ятого проходу можна було б уникнути, якби в наточувальному верстаті був калібр з діаметром 1,8 мм.

\section{ВИСНОВКИ}

Розроблено технологію холодного волочіння перегрітого дроту зі сталі Ст.2 без повторного відпалу, що забезпечує при витяжці за один прохід 1,20-1,52 і швидкостях волочіння від 0,245 до 0,518 м / с підвищення міцності до рівня, достатнього для використання дроту в якості обв'язувального матеріалу і заготовок для цвяхів.

На основі експериментальних даних отримано аналітичні залежності тимчасового опору і границі текучості перегрітого дроту від його витяжки в процесі волочіння.

Запропонована нерівність, яка зв'язує напруження, що виникає в початковий момент волочіння в перетині кінцевої загостреної ділянки дроту, і напруження зрізу задирок, утворених при загостренні, з тимчасовим опором сталі марки Ст. 2. Нерівність дозволяє розрахувати граничну витяжку на кожному волочильному проході.

\section{СПИСОК ВИКОРИСТАНОЇ ЛІТЕРАТУРИ}

1. Рудской А. И., Лунев В. А., Шаболдо О. Р. Волочение. Санкт-Петербург: Изд-во Политех. ун-та, 2011. $126 \mathrm{c}$

2. Радионова Л. В., Радионов А. А. Современное состояние и перспективы развития волочильного производства стальной проволоки. Машиностроение: сетевой электронный научный журнал. 2013. 1. С. 3-9.

3. Kukhar V. V., Grushko A. V., Vishtak I. V. Shape Indexes for Dieless Forming of Elongated Forgings with Sharpened End by Tensile Drawing with Rupture. Solid State Phenomena. 2018. 284, pp. 408-415.

DOI: https://doi.org/10.4028/www.scientific.net/SSP.284.408

4. Аніщенко О. С., Кухар В. В., Присяжний А. Г. Вплив термомеханічної обробки на властивості дроту з інвару. Проблеми трибологї. 2017. 3. С. 46-50.

5. Аніщенко О. С., Кухар В. В., Присяжний А. Г. Ізотермічне волочіння дроту для зварювання титанових листів корпусів підводних плавзасобів. Матеріали всеукраїнської науково-технічної конференції: Актуальні проблеми проектування, виготовлення і експлуатації озброєння та військової техніки, 17-19 травня 2017. Вінниця, ВНТУ. С.26-28.

6. Анищенко А. С. Структура и свойства проволоки из титанового сплава ПТ-7св после изотермического волочения. Письма о материалах. 2014. 4. 3. С.159-162.

7. Anishchenko O., Balalayeva E., Kukhar V., Agarkov V., Prysiazhnyi A., Aliieva L. Ensuring the Required Electrotechnical Properties during Recycling of Worn Trolley Wire. Modern Electrical and Energy System (MEES'2019); 2019 IEEE International Conference on Modern Electrical and Energy Systems (MEES), Sept. 23-25, 2019. Kremenchuk, Ukraine, pp. 482-485. DOI: https://doi.org/10.1109/MEES.2019.8896433

8. Харитонов В. А., Копьев А., Покачалов В. В. Дефекты проволоки. Виды. Способы контроля. Удаление. Магнитогорск: МГТУ, 2001. 64 с.

9. Малиночка Я. И., Ковальчук Г. З., Багнюк Л. М. Перегрев и пережог стали. Сталь. 1983. 9. С. $73-77$.

10. Грушко О. В., Слободянюк Ю. О., Ткаченко Р. С. Криві течії катанки марок G3Si1 та Св-08Г2С. Обработка материалов давлением. Краматорск: ДГМА. 2016. 1(42). С. 207-213. 
11. Пачурин Г. В., Филиппов А. А. Эффект пластической деформации при волочении и термической обработке на структуру и свойства стального проката. Международный журнал прикладных и фундаментальных исследований. Технические науки. 2014. 8. С. 93-98.

12. Grushko A. V., Kukhar V. V., Slobodyanyuk Yu. O. Phenomenological Model of Low-Carbon Steels Hardening during Multistage Drawing. Solid State Phenomena. 2017.265, pp. 114-123. DOI: https://doi.org/10.4028/www.scientific.net/SSP.265.114 $1976.560 \mathrm{c}$

13. Охрименко Я. М. Технология кузнечно-штамповочного производства. Москва: Машиностроение,

14. Недовизий И. Н., Тарнавский А. Л. Скоростное волочение низкоуглеродистой стальной проволоки. Москва: Металлургиздат, 1954. 186 с.

\section{REFERENCES}

1. Rudskoy A.I., Lunev V.A., Shaboldo O.R. Drawing. St. Petersburg: Polytechnic University Publishing House, 2011. 126 p. (in Russian).

2. Radionova L.V., Radionov A.A. Current state and development prospects of drawing production of steel wire. Mechanical engineering: network electronic scientific journal. 2013. 1, pp. 3-9. (in Russian).

3. Kukhar V.V., Grushko A.V., Vishtak I.V. Shape Indexes for Dieless Forming of Elongated Forgings with Sharpened End by Tensile Drawing with Rupture. Solid State Phenomena. 2018. 284, pp. 408-415. (in Ukrainian).

DOI: doi.org/10.4028/www.scientific.net/SSP,284.408

4. Anishchenko O.S., Kukhar V.V., Prysiazhnyi A.G. Influence of thermomechanical treatment on the properties of invar wire. Problems of tribology. 2017. 3, pp. 46-50. (in Ukrainian).

5. Anishchenko O.S., Kukhar V.V., Prysiazhnyi A.G. Isothermal wire drawing for welding titanium sheets of submarine hulls. Proceedings of the All-Ukrainian scientific and technical conference: Current issues of design, manufacture and operation of weapons and military equipment. May 17-19 2017. Vinnytsa: VNTU, pp.26-28. (in Ukrainian).

6. Anishchenko A. S. Structure and properties of PT-7sv titanium alloy wire after isothermal drawing. Material letters. 2014. 4. 3, pp.159-162. (in Russian).

7. Anishchenko O., Balalayeva E., Kukhar V., Agarkov V., Prysiazhnyi A., Aliieva L. Ensuring the Required Electrotechnical Properties during Recycling of Worn Trolley Wire. Modern Electrical and Energy System (MEES'2019); 2019 IEEE International Conference on Modern Electrical and Energy Systems (MEES). Sept. $23-25$. 2019. Kremenchuk, Ukraine, pp. 482-485. DOI: https://doi.org/10.1109/MEES.2019.8896433

8. Kharitonov V.A., Kopiev A.V., Pokachalov V.V. Wire defects. Kinds. Control methods. Removal. Magnitogorsk: MSTU. 2001, 64 p. (in Russian).

9. Malinochka Ya.I., Kovalchuk G.Z., Bagnyuk L.M. Overheating and burnout of steel. Steel. 1983. 9, pp. $73-77$. (in Russian)

10. Grushko O.V., Slobodyanyuk Yu.O., Tkachenko R.S. Curves of plastic flow of wire rod from steels of G3Siland Sv-08G2S brands. Materials Working by Pressure. Kramatorsk: DSEA. 2016. 1(42), pp.207-213. (in Ukrainian).

11. Pachurin G.V., Filippov A.A. The effect of plastic deformation during drawing and heat treatment on the structure and properties of rolled steel. International Journal of Applied and Basic Research. Technical science, 2014. 8, pp.93-98. (in Russian).

12. Grushko A.V. Kukhar V.V. Slobodyanyuk Yu.O. Phenomenological Model of Low-Carbon Steels Hardening during Multistage Drawing. Solid State Phenomena, 2017. 265, pp.114-123.

DOI: https://doi.org/10.4028/www.scientific.net/SSP.265.114

13. Okhrimenko Ya. M. Technology of forging and stamping production. Moscow: Mechanical Engineering, 1976. 560 p. (in Russian).

14. Nedoviziy I. N, Tarnavskiy A. L High-speed drawing of low-carbon steel wire. Moscow: Metallurgy, 1954. 186 p. (in Russian).

Аніщенко О. С. - канд. техн. наук, доц. ПДТУ;

E-mail: aas540628@gmail.com; https://orcid.org/0000-0002-1350-836X

Кухар В. В. $\quad$ - д-р техн. наук, проф. ПДТУ;

E-mail: kvv.mariupol@gmail.com; https://orcid.org/0000-0002-4863-7233

Присяжний А. Г. - канд. техн. наук, доц. ПДТУ;

E-mail: agp87514@gmail.com; http://orcid.org/0000-0001-8062-075X

ПДТУ - Державний вищій навчальний заклад «Приазовський державний технічний університет», м. Маріуполь. 